\title{
Isolation and Characterization of Mercury Resistant Bacteria from Haldia river sediments
}

\author{
Ankhi.Maiti ${ }^{1 *}$, Sagarika.Bhattacharyya ${ }^{2}$ \\ ${ }^{1,2}$ (Chemistry Department, Dr.S .C.Sur Degree Engineering College (JIS) West Bengal University of \\ Technology, Kolkata, India
}

\begin{abstract}
The Mercury is known as a toxic heavy metal. The present work is aimed to isolate and characterize mercury resistant bacterial strains from the Haldia dock area river sediment. Bacterial cells are grown in 10 ppm of $\mathrm{HgCl} 2$ containing nutrient media. These isolates were resistant up to $150 \mathrm{ppm}$ of mercury salt. The bacterial isolates were identified to belong to the genera: Serratia and Streptococcus or Enterococcus.. Many of the chosen isolates were tested for growth in a variety of antibiotics. Results of this study demonstrate the occurrence of diverse groups of marine bacteria capable of high tolerance to mercury. Mercury tolerant strains from dock area can be used to detect mercury toxicity in this type of polluted area and can be used for bioremediation of mercury toxicity.
\end{abstract}

Keywords: Bioremediation, MRB, Quorum sensing, Serratiae, Streptococcus.

\section{INTRODUCTION}

Mercury is known to be the most toxic heavy metal and it exists naturally in small amounts. However, its levels have risen in the environment due to contamination from anthropogenic activities [1]. Mercury binds to enzymes and proteins, thereby inactivates vital cell functions [2]. Even small amounts of mercury can become toxic for all organisms. Mercury pollution released into the environment becomes a serious threat when it settles into waterbodies where it builds up in aquatic organisms that we eat. Its contamination in soil, water can be major problem for human health, industrial process, and defense related sites worldwide.In human body, excessive mercury is a neurotoxin, interfering mostly with the brain and nervous system. Even in low doses, mercury can affect a child's development. In adults, mercury poisoning can adversely affect fertility blood pressure regulation; memory loss, tremors, and vision loss .People affected by mercury pollution are also found to be resistant to several antibiotics [3].

Microbes which are resistant to mercury convert inorganic mercury to methlymercury, which has higher toxicity level. Thus a small environmental concentration of mercury and subsequent presence of MRB (mercury resistant bacteria) at a site increases the chances of accumulation of mercury in higher levels of food chain through biomagnifications. Studies show that many Indian coastal areas are polluted by mercury compounds and the amount ranges from 2 to $15 \mathrm{ng}$ of dissolved mercury. The environments near Haldia dock area has shown very low $\mathrm{pH}$ levels (4.6 to 5), thus favoring the production of methyl mercury. The aim of this study is to identify and isolate the mercury resistant bacteria and to utilize them toxic metal bioremediation.

\section{MATERIALS AND METHODS}

\subsection{SEDIMENT COLLECTION AND STORAGE}

Sediment samples were collected from three zones of Haldia dock area riverbeds for the isolation of mercury resistant bacteria. The samples were collected with nitric acid pre-rinsed $1 \mathrm{~L}$ plastic container for chemical analysis and sterile glass container for microbial culturing. After collection, the samples were placed in cooler boxes with ice bags whilst being transported to the laboratory and kept at about $4{ }^{\circ} \mathrm{C}$ before chemical and microbial analysis. During sample collection the $\mathrm{pH}$ of water was found acidic $(\mathrm{pH} 4.6-5)$ and temperature was $25^{0} \mathrm{C}$. The chemical ingredients for the experiment were purchased from Himedia chemicals, India.

\subsection{ISOLATION OF MERCURY RESISTANT BACTERIA}

Isolation of Hg resistant bacteria was performed by primary enrichment method and directly plating on amended mercury. For the isolation of mercury resistant bacteria, $1 \mathrm{~g}$ of sample was inoculated in sea water nutrient broth, (composition: peptone $5.0 \mathrm{~g}$, beef extract $3.0 \mathrm{~g}$, aged seawater $750 \mathrm{ml}$ and deionised water $250 \mathrm{ml}$; final $\mathrm{pH} 7.5$ ). To induce selective growth of only mercury resistant bacteria about $10 \mathrm{ppm} \mathrm{HgCl}_{2}$ salt was added singly to sterile medium prior to inoculation. Tubes are incubated at $24^{\circ} \mathrm{C}$ for 24 hours in shaker. Growth was determined visibly by turbidity and streaking of a loopful of liquid culture on Luria Bertani (LB) agar plates supplemented with $\mathrm{HgCl}_{2}$. MRB were isolated by spreading techniques on agar plates with $\mathrm{HgCl}_{2}$. Single colonies were obtained following enrichment techniques. A simultaneous negative control test was done with available 
bacteria on solid media plates containing mercuric chloride. The pure cultures of isolated strains were preserved in agar slants containing $10 \mathrm{ppm}$ of mercury salt in vials under refrigerated $4^{0} \mathrm{C}$ conditions.

\subsection{ENUMERATION OF VIABLE CELL COUNT}

All samples were serially diluted in Phosphate-Buffered Saline (PBS) (2.2 g of $\mathrm{NaH}_{2} \mathrm{PO}_{4}$ per liter, $6 \mathrm{~g}$ of $\mathrm{Na}_{2} \mathrm{HPO}_{4}$ per liter, $5.8 \mathrm{~g}$ of $\mathrm{NaCl}$ per liter). About $0.1 \mathrm{~mL}$ of each dilution were spread on Luria Bertani agar ( $10 \mathrm{~g}$ of peptone per liter, $5 \mathrm{~g}$ of yeast extract per liter, $10 \mathrm{~g}$ of $\mathrm{NaCl}$ per liter, $12 \mathrm{~g}$ of agar per liter) supplemented with $10 \mathrm{mg}$ of $\mathrm{HgCl}_{2}$ per liter and without $\mathrm{HgCl}_{2}$. The plates were incubated at $24^{\circ} \mathrm{C}$ for 48 hours. After incubation period, the appeared colonies on both LB agar containing $\mathrm{Hg}$ (II) and without $\mathrm{Hg}$ (II) were enumerated using total viable plate count method [4].

\subsection{MORPHOLOGICAL AND PHYSIOLOGICAL CHARACTERIZATION OF ISOLATES}

2.4.1. COLONY AND CELL MORPHOLOGY

Size, shape, color, elevation and margins of bacterial colonies were observed for 24 hours incubated culture on agar plates containing 10ppm mercury salt. Cells were observed under microscope and motility test done to check presence of flagella.

\subsubsection{TEMPERATURE TOLERANCE}

To study the effect of temperature on isolated MRB strains about $100 \mu \mathrm{l}$ of overnight grown culture was dispensed into test tubes and incubated at different temperature like $4^{\circ} \mathrm{C}, 11^{\circ} \mathrm{C}, 24^{\circ} \mathrm{C}, 30^{\circ} \mathrm{C}, 38^{0} \mathrm{C}$ for 24 hours. Optical density (OD) measured at $600 \mathrm{~nm}$ using spectrophotometer and results recorded.

\subsubsection{Metal TOLERANCE}

The viability of cells following exposure to high levels of mercury was studied. Chosen isolates were grown at different concentrations of mercury metal. Resistant strains grown on LB broth amended with $\mathrm{HgCl}_{2}$ and incubating it at $23^{\circ} \mathrm{C}$ for $24 \mathrm{hr}$. Six LB media with different concentration of mercury $(4 \mathrm{ppm}, 10 \mathrm{ppm}$, $25 \mathrm{ppm}, 50 \mathrm{ppm}, 100 \mathrm{ppm}$ and $150 \mathrm{ppm}$ ) are inoculated with $100 \mu \mathrm{l}$ of bacterial suspension and the tubes were incubated at $23^{\circ} \mathrm{C}$ for $24 \mathrm{hr}$. Optical density recorded at $600 \mathrm{~nm}$ to see growth pattern.

\subsection{BIOCHEMICAL CHARACTERIZATION}

A Biochemical characterization of isolated MRB strains were done by following the Bergey's manual of determinative bacteriology [5].Himedia Rapid Biochemical Identification kit was used in this study. Single cell isolated colony was picked up and inoculated in $10 \mathrm{ml}$ sea water nutrient broth and incubated at $24^{\circ} \mathrm{C}$ for 24 hours. Identification kit wells were inoculated with $50 \mu \mathrm{l}$ of the above inoculums by surface inoculation method and kept for inoculation at $24^{\circ} \mathrm{C}$ for $18-24$ hours. At the end of the incubation period, the appeared colonies were identified with gram staining and conventional biochemical tests

\subsection{ANTIBIOTIC SENSITIVITY}

The antibiotic resistance characteristics of mercury resistant bacterial isolates were studied by antibiotic disc diffusion method [6]. The antibiotics used were Streptomycin $(4 \mu \mathrm{g} / \mathrm{ml})$, Ampicillin $(25 \mu \mathrm{g} / \mathrm{ml})$, Chloramphenecol $(25 \mu \mathrm{g} / \mathrm{ml})$, Penicillin $(25 \mu \mathrm{g} / \mathrm{ml})$, Gentamicin $(4 \mu \mathrm{g} / \mathrm{ml})$, and Rifampicin $(4 \mu \mathrm{g} / \mathrm{ml})$, Cephalosporin ,Vancomycin, Carbapenems .The antibiotic discs were placed on nutrient agar plates previously seeded with $18 \mathrm{hr}$ broth culture of the test organisms. The plates were incubated at $25^{\circ} \mathrm{C}$ for $24 \mathrm{hr}$, after which diameter of zones of inhibition and MIC was examined. Earlier; the potencies of all the antibiotics used in the study were confirmed using susceptible E. coli strains.

\section{RESULT AND DISCUSSION}

Sediments samples of Haldia dock area were directly inoculated onto selective medium supplemented with 10ppm mercury salt. During this direct selection of mercury resistant bacteria using high level of $\mathrm{HgCl}_{2}$ in media, it is possible that some low level MRB growth was inhibitend [7]. On enrichment and streaking to isolate single colonies, two distinct types of isolates $(1 \& 2)$ were seen on sea water nutrient media amended with $\mathrm{HgCl}_{2}$. Previous studies suggest that generally the optimal growth temperature of MRB is around $37^{\circ} \mathrm{C}$, but the fact that only two isolates obtained, may be due to low temperature $\left(23^{\circ} \mathrm{C}\right)$ during sample collection and high amonut of mercury salt used in preliminary isolation media.During bacterial enumeration, the total viable counts ranged from $1.7 \times 10^{7} \mathrm{cfu} \mathrm{g}^{-1}$ in $\mathrm{SC} 1$ sediment samples to $2.1 \mathrm{X} 10^{7} \mathrm{cfu} \mathrm{g}^{-1}$ in $\mathrm{SC} 2$ sediment samples. The frequencies of resistance to $\mathrm{Hg}$ varied from $2 \%$ in to $22 \%$ (Table 1 ).

Further study on mercury resistant bacteria showed variability in growth pattern with time and concentration of $\mathrm{HgCl}_{2}$. Generally lag phase persisted for 1-2 hours. The all isolated strains could resist upto $150 \mathrm{ppm}$ of $\mathrm{Hgcl}_{2}$ in LB agar media (Fig 1).The isolate1 showed more defined growth at $4 \mathrm{ppm}$ and $50 \mathrm{ppm}$ of mercury salt 
concentrations, while at $150 \mathrm{ppm}$ growth was considerable reduced due to the high concentration metal stress (Fig 2). The $\mathrm{pH}$ tolerance studies showed preferred $\mathrm{pH}$ of the isolates was in acidic range (Fig 3). The preferred $\mathrm{pH}$ was 5 , which was reflected by the increase in value of optical density at this $\mathrm{pH}$. Growth decreased with higher alkaline $\mathrm{pH}$. Temperature sensitivity test showed optimal temperature of the isolated MRBs was $24^{0} \mathrm{C}$. (Fig 4).The strains showed no growth at $37^{\circ} \mathrm{C}$ even when incubated for 48 hours.

Morphological studies showed colonies circular, flat and some convex and they had entire margins. Isolate one showed cells with distinct red pigment.The second type isolated colony cells were off white in color (Table 2).All strains could resist Chloramphenecol, Penicillin, Ampicillin, and sensitive to Streptomycin, Gentamicin, and Rifampicin (Table3). Single colonies were taken further to identify the bacteria at generic level $[11,12$, and 13].Table 4 shows the biochemical characteristics of the isolate 1 and 2 . The isolate 1 had high salt tolerance and had low minimal growth temperature. These isolates were gram negative short rods, having non diffusible red pigments. Isolate 1 was able to grow in CT agar plates. These are facultative anaerobes and give positive catalase reaction. The production of red pigment of isolate 1 was suppressed through quorum sensing at high levels of mercury and antibiotics in media.It is known that Serratia genus produce a distinctive red pigment, prodigiosin. From the antibiotic resistance and biochemical characteristic profile study of this isolate1, is affiliated to the genus Serratia [9, 10,] of the family of Enterobactereacea. Based on generic analysis using key characters of genus description it was found isolate 1 is Serratia mercescens. Testing further the isolate 1 in milk agar plate gave a positive casein test. The isolate 2 was off white circular colonies with cells existing in pairs (diplococcal).These being gram positive were assigned to be of genus Streptococcus or Enterococcus based on their biochemical characters.

IV. Figures and Tables

Table 4. 1 Frequencies of $\mathrm{Hg}$ resistant.

\begin{tabular}{|l|l|l|l|}
\hline Sample & Total bacteria $(\mathrm{cfu} / \mathrm{g})$ & $\begin{array}{l}\text { Hg resistant Bacteria } \\
(\mathrm{cfu} / \mathrm{g})\end{array}$ & $\begin{array}{l}\text { Hg resistant } \\
\text { Bacteria }(\%)\end{array}$ \\
\hline SC1 & $1.7 \times 10^{7}$ & $3.5 \times 10^{5}$ & 2.058 \\
\hline SC2 & $2.1 \times 10^{7}$ & $4.7 \times 10^{6}$ & 22.38 \\
\hline SC3 & $1.8 \times 10^{7}$ & $2.2 \times 10^{6}$ & 12.22 \\
\hline
\end{tabular}

Table 4. 2. Colony Morphology

\begin{tabular}{|c|l|l|l|}
\hline Isolate No. & Color & Shape & Elevation \\
\hline 1 & red & circular & flat \\
\hline 2 & Off white & circular & convex \\
\hline
\end{tabular}

Table 4. 3. Antibiotic resistance profile

\begin{tabular}{|l|c|c|c|c|}
\hline Antibiotic & \multicolumn{2}{|c|}{ Isolate No. } & \multicolumn{2}{l|}{} \\
\hline & isolate $_{11}$ & isolate $_{12}$ & isolate $_{21}$ & isolate $_{22}$ \\
\hline Chloramphenecol & $\mathrm{R}$ & $\mathrm{R}$ & $\mathrm{S}$ & $\mathrm{R}$ \\
\hline Penicillin & $\mathrm{R}$ & $\mathrm{R}$ & $\mathrm{S}$ & $\mathrm{R}$ \\
\hline Streptomycin & $\mathrm{S}$ & $\mathrm{S}$ & $\mathrm{S}$ & $\mathrm{S}$ \\
\hline Gentamicin & $\mathrm{S}$ & $\mathrm{S}$ & $\mathrm{S}$ & $\mathrm{S}$ \\
\hline Rifampicin & $\mathrm{R}$ & $\mathrm{R}$ & $\mathrm{R}$ & $\mathrm{R}$ \\
\hline Ampicillin & $\mathrm{R}$ & $\mathrm{R}$ & $\mathrm{S}$ & $\mathrm{S}$ \\
\hline Clindamycin & $\mathrm{R}$ & $\mathrm{R}$ & $\mathrm{S}$ & $\mathrm{R}$ \\
\hline Erythromycin & $\mathrm{R}$ & $\mathrm{R}$ & $\mathrm{S}$ & $\mathrm{S}$ \\
\hline Cephalosporin & $\mathrm{R}$ & $\mathrm{R}$ & $\mathrm{R}$ & $\mathrm{R}$ \\
\hline Vancomycin & $\mathrm{S}$ & $\mathrm{S}$ & $\mathrm{S}$ & $\mathrm{S}$ \\
\hline Carbapenems & $\mathrm{R}$ & $\mathrm{R}$ & $\mathrm{R}$ & $\mathrm{R}$ \\
\hline
\end{tabular}

$\mathrm{R}=$ Resistant, $\mathrm{S}=$ Sensitive 
Table 4. 4. Biochemical characterization

\begin{tabular}{|l|c|c|}
\hline \multirow{2}{*}{ Characteristics } & \multicolumn{2}{|c|}{ MRB Isolates } \\
\cline { 2 - 3 } & isolate 1 & isolate 2 \\
\hline Gram reaction & - & + \\
\hline shape & Short rods & Cocci \\
\hline Motility & + & - \\
\hline Color & Red & off white \\
\hline Oxidase & - & - \\
\hline Growth at $4 \% \mathrm{NaCl}$ & + & - \\
\hline H2S production & - & - \\
\hline Voges proskar & + & + \\
\hline Glucose fermentation & + & - \\
\hline Catalase & + & - \\
\hline Urease & - & $\mathrm{Nd}$ \\
\hline Nitrate broth & + & - \\
\hline Citrate & + & $\mathrm{Nd}$ \\
\hline Starch hydrolysis & - & - \\
\hline Pyrrolidonyl arylamidase & - & + \\
\hline Growth at37 ${ }^{0} \mathrm{C}$ & - & - \\
\hline Growth at $24^{0} \mathrm{C}$ & + & + \\
\hline Indole test & - & + \\
\hline Methyl red test & + & - \\
\hline Lipase & + & + \\
\hline DNase & + & - \\
\hline Proteinase & $\mathrm{Nd}$ & - \\
\hline Mackoncy agar & + & - \\
\hline Phenylalanin deaminase & + & - \\
\hline Inulin & + & - \\
\hline Raffinose & + & - \\
\hline & & - \\
\hline
\end{tabular}

$\mathrm{Nd}=$ Not determined,$(+)=$ positive,$(-)=$ negative,

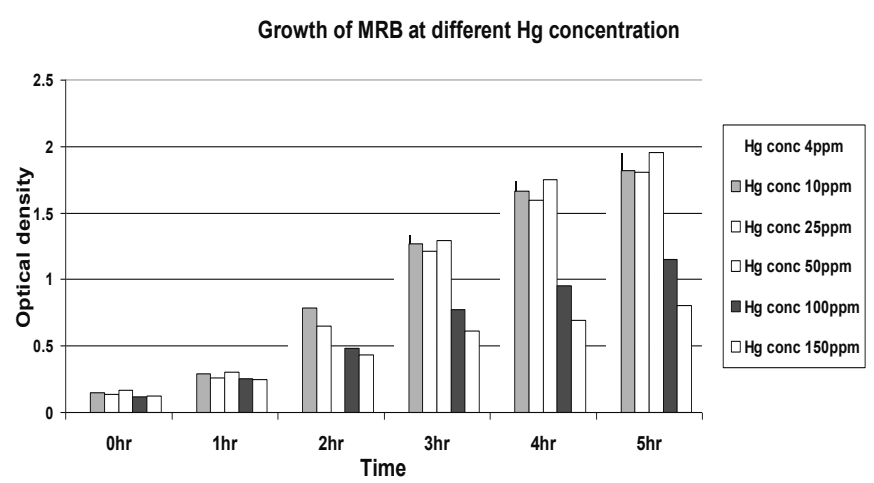

Fig 1: Growth pattern of MRB isolates at various $\mathrm{Hg}+2$ concentrations.

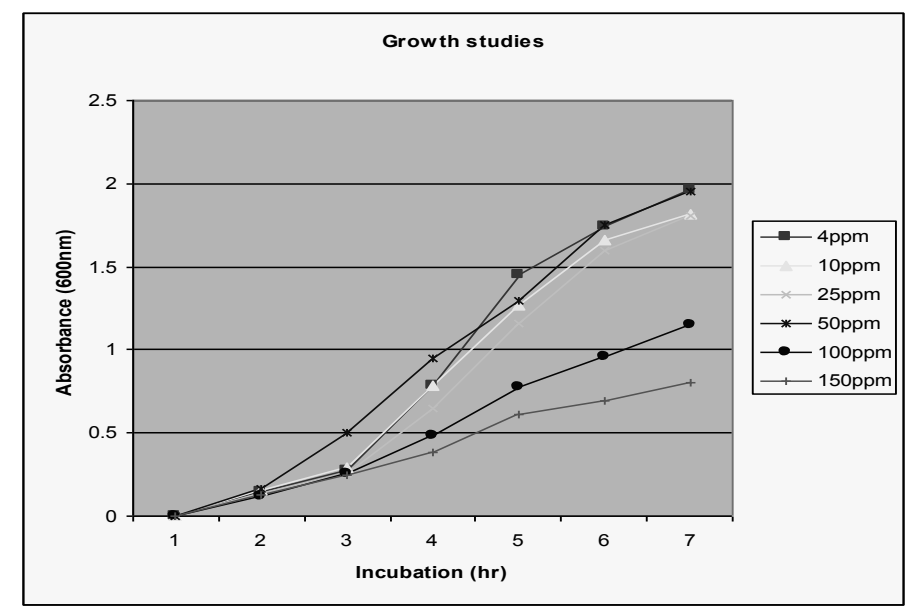

Fig 2: Shows the growth pattern of isolate 1 at various mercury salt concentration 


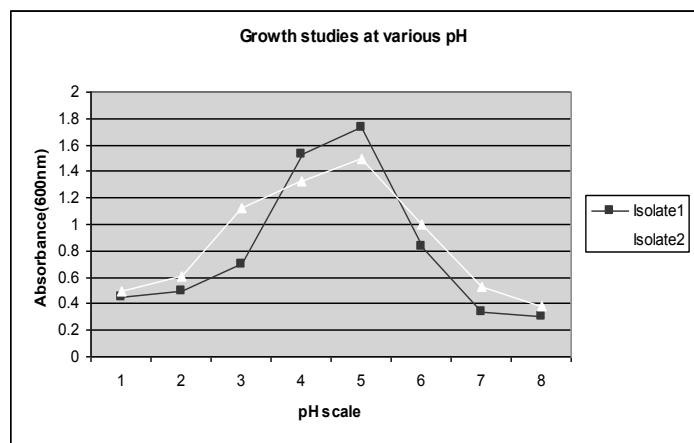

Fig 3: Shows the growth pattern of isolate $1 \& 2$ at various $\mathrm{pH}$

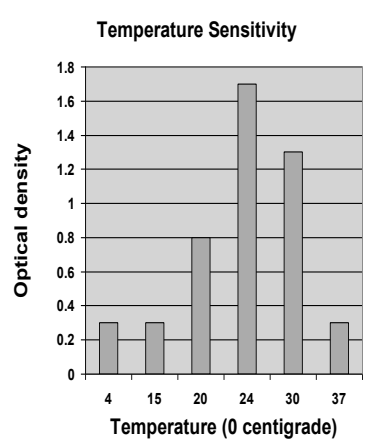

回

Fig 4: Shows the growth of isolate $\mathrm{SC} 1$ at various temperatures

\section{Conclusion}

The results achieved in the present study show frequencies of mercury resistant bacteria in the contaminated areas (dock) are high and thus a potential threat to the nearby population. The study successfully isolated two mercury resistant bacteria strains. Based on biochemical characteristics they are identified to two different genera: Serratia and Streptococcus orEnterococcus. These isolates have high potential to remove $\mathrm{Hg}$ from the dock area (bioremediation) as can tolerate mercury contamination up to $150 \mathrm{ppm}$ which can be further investigatend to check their maximum mercury tolerance level. These can be used in future for detection of mercury toxicity in potential polluted areas. Future investigations can be done at genetic level to know their antibiotic resistance properties of MRB, which may help treatment of mercury affected people.

\section{Acknowledgements}

We are obliged to Biotechnology department, HIT (Haldia) and Chemistry department, Dr. Sudhir Chandra Sur Degree Engineering College, (JIS group) Dumdum Kolkata West Bengal. We are thankful to the Management (JIS) for their constant encouragement in research work.

\section{REFERENCES}

[1] Nascimento, A.M.A. and E.C. Souza, 2003. Operon mer: bacterial resistance to mercury and potential for bioremediation of contaminated environments. J. Genet. Mol. Res., 2: 92-101

[2] Wagner Dobler, I., H. Von Canstein, K.N. Timmis, Y. Li and W.D. Deckwer, 2000. Removal of mercury from chemical wastewater by microorganisms in technical scale. Environ. Sci. Tecnhnol., 34: 4628-4634.

[3] Calomiris JJ, Armstrong JL, Seidler RJ., Association of metal tolerance with multiple antibiotic resistances of bacteria isolated from drinking water. Appl Environ Microbiol. 1984 Jun;47(6):1238-42.

[4] Prescott, L.M. and J.P. Harley, 2002. Laboratory Exercises in Microbiology. 1st Edn., McGraw Hill Publ., New York, USA. ISBN: 978-0-471-42082-8. Note that the journal title, volume number and issue number are set in italics.

[5] Bergey, D. H. (David Hendricks), Breed, Robert S. (Robert Stanley), Bergey's manual of determinative bacteriology American Society for Microbiology; (1957)

[6] Note that the title of the book is in lower case letters and italicized. There is no comma following the title. Place of publication and publisher are given.

[7] Bauer AW, Kirby WM, Sherris JC, Turck M. Antibiotic susceptibility testing by a standardized single disk method. Am J Clin Pathol. 1966 Apr; 45(4):493-496 Note that the place of publication, publisher, and year of publication are enclosed in brackets. Editor of book is listed before book title.

[8] Osborn, A. M., Bruce, K. D., Strike, P. \& Ritchie, D. A. (1993). Polymerase chain reaction-restriction fragment length polymorphism analysis shows divergence among mer determinants from Gram-negative soil bacteria indistinguishable by DNADNA hybridization. Appl Environ Microbiol 59, 4024-4030.

[9] R. Pike1, V. Lucas2, P. tapleton, M. S. Gilthorpe, G. Roberts, R. Rowbury, H. Richards, P. Mullany and M. Wilson, Prevalence and antibiotic resistance profile of mercury-resistant oral bacteria from children with and without mercury amalgam fillings, Journal of Antimicrobial Chemotherapy, Volume 49, Issue 5 Pp. 777-783 
[10] Yunsop Chong, Kui Nyung Yi and Samuel Y.Lee, Biochemical Characterisation| and antibiotic Susceptibilities of Serratia marcescens isolated from Clinical specimens, Yonsei Medical Journal Vol 19, No.1, 1978.

[11] N. Mirzaei, F. Kafilzadeh and M. Kargar, 2008. Isolation and Identification of Mercury Resistant Bacteria from Kor River, Iran. Journal of Biological Sciences, 8: 935-939.

[12] Enny Zulaika1*, Langkah Sembiring2 and Agoes Soegianto3, Characterization and Identification Of Mercury-resistant Bacteria From Kalimas River Surabaya-Indonesia By Numerical Phenetic Taxonomy, J. Basic. Appl. Sci. Res., 2(7)7263-7269, 2012

[13] Shazia Afrasayab, Azra Yasmin, Shahida Hasnain, Characterization of some Indigenous mercury resistant bacteria from polluted environment, Pakistan Journal of Biological sciences 5(7): 792-797, 2002

[14] C.Edward, G. S. Selvam and Kiyoshi Omine, Isolation, identification and characterization of heavy metal resistant bacteria from sewage.Internatinal Joint symposium on Geodisaster Prevention and Geoenvironment in Asia JS Fukuoka 2009. 